\section{In Vitro Storage Conditions for Mint Germplasm}

\author{
Barbara M. Reed ${ }^{1}$ \\ U.S. Department of Agriculture, Agricultural Research Service, National \\ Clonal Germplasm Repository, 33447 Peoria Road, Corvallis, \\ OR 97333-2521
}

Additional index words. cold storage, germplasm storage, Mentha sp., micropropagation, room-temperature storage

\begin{abstract}
Four tissue-cultured mints, Mentha arvensis L., M. spicata L., M. suaveolens Ehrh. hybrid, and M. suaveolens cv. Variegata, were evaluated for survival during storage in media containing three concentrations of $\mathrm{N}$ and in four light and temperature regimes. Shoots were placed in plastic, five-chamber, tissue-culture bags on Murashige and Skoog medium (1962) containing $25 \%, 50 \%$, and $100 \%$ of the normal $N$ concentration (MS-N) and stored at $4{ }^{\circ} \mathrm{C}$ and $-1{ }^{\circ} \mathrm{C}$ in darkness, at $4{ }^{\circ} \mathrm{C}$ with a 12 -hour photoperiod, and at $25^{\circ} \mathrm{C}$ with a 16-hour photoperiod. Shoots of all four genotypes stored at $25^{\circ} \mathrm{C}$ were in excellent condition after 6 months but required subculture after 18 months. Condition ratings of stored shoots varied with genotype and $\mathrm{N}$ concentration. Cultures survived longest at $4{ }^{\circ} \mathrm{C}$ with a 12-hour photoperiod on 50\% MS-N. Under this regime, all four genotypes were rated in good condition at 30 months but declined to poor condition by 36 months. Based on these data, I recommend that mint cultures be stored on MS medium with $50 \%$ MS-N at $4{ }^{\circ} \mathrm{C}$ with a 12-hour photoperiod. This regime should provide a minimum of 24 to 36 months of storage before subculture is required. Cold-sensitive genotypes could be stored for 18 months at $25{ }^{\circ} \mathrm{C}$ on $50 \%$ MS-N medium.
\end{abstract}

Breeders use collections of valuable plant germplasm to develop cultivars with improved crop yield and disease and insect resistance. Exotic germplasm, even that without currently identified economically important traits, requires safe storage. Obscure genes from these plants may provide solutions to new disease, insect, environmental, or crop production problems (Westwood, 1989). The United States produces $\$ 112$ million of peppermint and spearmint oil each year and new oil flavor components are under investigation (Chambers and Hummer, 1992). Mint germplasm must be preserved as clonal field-grown or potted plants because many cultivars are sterile. The two commercial mint types, peppermint and spearmint, are sterile hybrids and maintenance of specific genotypes is highly important to the mint oil industry. Mints can be readily cultured in vitro, although they may have associated internal bacterial contaminants (Buckley et al., 1995; Gunning and Lagerstedt, 1985; Reed et al., 1995).

Some clonal crops are kept in slow-growth storage as in vitro cultures for germplasm conservation (Ashmore, 1997; Engelmann, 1991; Withers, 1991; Withers et al., 1990). Previously, mint cultures held at the National Clonal Germplasm Repository (NCGR) were

Received for publication 17 Aug. 1998. Accepted for publication 3 Nov. 1998. The technical assistance of Carolyn Paynter is greatly appreciated. Use of trade names in this publication does not imply endorsement of the U.S. Dept. of Agriculture (USDA). The cost of publishing this paper was defrayed in part by the payment of page charges. Under postal regulations, this paper therefore must be hereby marked advertisement solely to indicate this fact.

${ }^{1}$ E-mail: reedbm@bcc.orst.edu stored at $4{ }^{\circ} \mathrm{C}$ in darkness in $13 \times 100 \mathrm{~mm}$ glass tubes on MS (Murashige and Skoog, 1962) medium. Under these storage conditions, $50 \%$ of the cultures were lost to fungal or bacterial contamination (Reed, unpublished data). These losses were reduced by changing storage vessels from glass tubes to polyethylene bags (Reed, 1991). The objective of this study was to contrast three MS medium N concentrations, four light and temperature conditions, and four genotypes in an effort to prolong in vitro storage of mint germplasm.

\section{Materials and Methods}

Four in vitro-grown mints [Mentha arvensis (NCGR local number 185.001), M. spicata (75.001), M. suaveolens hybrid (202.001), and M. suaveolens cv. Variegata (587.001)] were multiplied in Magenta GA7 boxes on $40 \mathrm{~mL}$ MS medium containing 2.2 ( $\mathrm{M} N^{6}$-benzyladenine (BA) and $0.5 \mu \mathrm{M}$ indole-3-butyric acid (IBA), 0.3\% Bitek agar (Difco, Detroit), and $0.125 \%$ Gelrite (Schweitzer-Hall, South Plainfield, N.J.) at $\mathrm{pH}$ 5.7. Shoots were harvested from 3-week-old cultures. Shoot tips and internodal sections $(2.5-3.0 \mathrm{~cm})$ were placed in five-cell Starpac bags (Garner Enterprises, Willis, Texas) on three formulations of MS medium (10 mL/cell) containing $0.3 \%$ agar and $0.15 \%$ Gelrite, but no growth regulators. Shoots stored at $25{ }^{\circ} \mathrm{C}$ in light were placed in bags with $20 \mathrm{~mL}$ medium per cell, as moisture loss is greater at the higher temperature (Reed, 1993). The medium contained $100 \%, 50 \%$, or $25 \%$ of the standard MS N concentrations $(100 \%, 50 \%$, and $25 \% \mathrm{MS}-\mathrm{N})$.

Shoots were sealed in tissue culture bags and grown in the growth room for 1 week [ 25 ${ }^{\circ} \mathrm{C}$, 16-h photoperiod, $25 \mu \mathrm{mol} \cdot \mathrm{m}^{-2} \cdot \mathrm{s}^{-1}$ photo- synthetic photon flux $(P A R)]$. Shoots destined for $4{ }^{\circ} \mathrm{C}$ and $-1{ }^{\circ} \mathrm{C}$ storage were then cold acclimatized $\left(8 \mathrm{~h}, 22^{\circ} \mathrm{C}\right.$ day $/ 16 \mathrm{~h},-1^{\circ} \mathrm{C}$ night $)$ for 1 week before storage. One bag of each treatment with five cells (replicates) was placed in each storage environment. Shoots were stored in four environments: $4{ }^{\circ} \mathrm{C}$ in darkness or $4{ }^{\circ} \mathrm{C}$ with a 12 -h photoperiod $(25 \mu \mathrm{mol}$. $\mathrm{m}^{-2} \cdot \mathrm{s}^{-1}$ PAR from cool white fluorescent bulbs), $-1{ }^{\circ} \mathrm{C}$ in darkness, or $25^{\circ} \mathrm{C}$ with a $16-\mathrm{h}$ photoperiod $\left(10 \mu \mathrm{mol} \cdot \mathrm{m}^{-2} \cdot \mathrm{s}^{-1}\right)$.

After 6, 18, 24, 30, 36, 48, and 54 months of storage in the four environments, shoots were rated on a vigor scale of 0 to 5 , based on plant appearance: 5 = dark green leaves and stems, no etiolation; 4 = green leaves and stems, little etiolation; $3=$ shoot tips and upper leaves green, some etiolation, 2 = shoot tips green, leaves and stems mostly brown, base may be dark brown, should be removed for subculture; 1 = plant mostly brown, only extreme shoot tip green, much of base dark brown; $0=$ plant totally brown, no visible green on shoot tip, dead.

A completely randomized design was used with genotype, $\mathrm{N}$ concentration, and storage environment (light/temperature) as factors for the cold storage experiments. Warm storage data were analyzed separately with genotype and $\mathrm{N}$ concentration as factors. Data were analyzed for ANOVA using the factor program on MSTATC (1988).

\section{Results and Discussion}

For mint plants stored at $25^{\circ} \mathrm{C}$ in the light, the MS-N concentration was the most important factor and the interaction of genotype and MS-N concentration was also significant (Table 1). Each of the genotypes survived growth room storage at $25{ }^{\circ} \mathrm{C}$ for up to 18 months. Their mean vigor rating was 3.8 at 6 months, but declined to below 2 by 18 months, at which time they required subculture (Fig. 1a). At $25^{\circ} \mathrm{C}$, ratings varied with genotype and MS-N: M. spicata and 'Variegata' on $50 \%$ MS-N remained in good condition (ratings of 3.4 and 2.8) at 18 months, but were dead by 24 months; $M$. arvensis and $M$. suaveolens hybrid shoots on $50 \%$ MS-N were rated poor (mean $1.2)$ at 18 months; and most shoots on treatments other than 50\% MS-N were dead at 18 months (data not shown).

The three-way interaction (genotype $\times$ environment $\times$ MS-N concentration) was significant for cold-stored shoots after 24 months

Table 1. Analysis of variance of condition ratings (1 $=$ poor $;=$ good) for in vitro-grown shoots of four mint genotypes (Mentha arvensis, M. spicata, M. suaveolens hybrid, and $M$. suaveolens cv. Variegata) stored at $25^{\circ} \mathrm{C}$ with a 16 -h photoperiod for 18 months on Murashige and Skoog medium with $25 \%, 50 \%$, or $100 \%$ MS nitrogen concentrations (MS-N).

\begin{tabular}{lrc}
\hline \hline Source & df & Mean square \\
\hline Genotype $(\mathrm{G})$ & 3 & $5.2^{* * *}$ \\
MS-N concentration & 2 & $19.5^{* * *}$ \\
G $\times$ MS-N & 6 & $1.7^{*}$ \\
Error & 48 & 0.7 \\
\hline
\end{tabular}

${ }^{* * *}$ Significant at $P \leq 0.05$, or 0.001 , respectively. 
at low temperatures, with environment having the greatest influence (Table 2, Fig. 2). After 24 months of storage, the best ratings were obtained for shoots stored at $4{ }^{\circ} \mathrm{C}$ with a 12 -h photoperiod; at $-1^{\circ} \mathrm{C}$ and $4{ }^{\circ} \mathrm{C}$ shoots stored in darkness were generally near or below ratings of 2 , and in some treatments all shoots were dead.

Cultures of $M$. arvensis, M. suaveolens hybrid, and 'Variegata' grown at $4{ }^{\circ} \mathrm{C}$ in the light were rated significantly better than those in the other cold treatments at all MS-N concentrations (Fig. 2 a, c, and d). M. spicata ratings were best at $4{ }^{\circ} \mathrm{C}$ in light with $100 \%$ and 50\% MS-N (Fig. 2b). Both M. suaveolens genotypes did poorly (mean rating $<1$ ) in the dark conditions (Fig. $2 \mathrm{c}$ and d), while $M$. arvensis and $M$. spicata plants were rated 1 or greater in the dark (Fig. $2 \mathrm{a}$ and b).

Cultures stored at $4{ }^{\circ} \mathrm{C}$ with a 12 -h photoperiod continued to have viable ratings $(>2)$ at 30 months (Fig. 1a). The three-way interaction of factors remained significant and the environmental effect remained strong (Table 2). M. spicata and $M$. arvensis cultures were viable at 30 months under the three coldstorage conditions, but ratings were highest at $4{ }^{\circ} \mathrm{C}$ with light; $M$. suaveolens hybrid and 'Variegata' shoots were rated $<1$ except when grown at $4{ }^{\circ} \mathrm{C}$ in light (data not shown). The optimum $\mathrm{N}$ concentration varied with genotype, but 50\% MS-N was suitable for all four genotypes (Fig. 1b). After storage for 48 and 54 months, all genotypes rated $<2$, and therefore these conditions were not acceptable for continued storage and survival of the plants.

Plants of the four genotypes varied in their ratings under the environments tested. $M$. arvensis had the highest ratings in the coldstorage environments and $M$. suaveolens hybrid and 'Variegata' had the lowest (Fig. 1c). In warm $\left(25^{\circ} \mathrm{C}\right)$ storage conditions $M$. spicata and 'Variegata' had the highest ratings of the four mints tested. The highest overall ratings for up to 30 months were in the $4{ }^{\circ} \mathrm{C}$ light environment (Fig. 1a). The response of shoots grown at $25^{\circ} \mathrm{C}$ to a lower $\mathrm{N}$ concentration was similar to that of raspberry shoots grown in vitro on $6 \%, 25 \%$, and $100 \% \mathrm{MS}-\mathrm{N}$, where reducing $\mathrm{N}$ concentrations improved ratings significantly (Reed, 1993). Reducing $\mathrm{N}$ in the medium is also beneficial for storage of cultures of chilling-sensitive grape (Vitis sp.) (Moriguchi and Yamaki, 1989).

Duplicate cultures of mint were stored at NCGR in the early 1980 s in $13 \times 100 \mathrm{~mm}$ tubes at $4{ }^{\circ} \mathrm{C}$ in darkness for 1 year (Gunning and Lagerstedt, 1985). Most genotypes remained alive, but $50 \%$ or more were contaminated by bacteria or fungi (Reed, unpublished). Genotypic variation was evident in mint cultures (116 genotypes) stored in plastic, five-chamber, tissue-culture bags at NCGR at $4{ }^{\circ} \mathrm{C}$ in darkness from 1989-95; these cultures could be stored from 0.7 to 5.7 years before requiring subculture (Reed and Chang, 1997). The results presented here indicate that mint cultures can be stored best on MS medium with $50 \% \mathrm{~N}$ concentration at $4^{\circ} \mathrm{C}$ with a 12 -h photoperiod. This regime should provide a minimum of 24 to 36 months of storage before subculture is

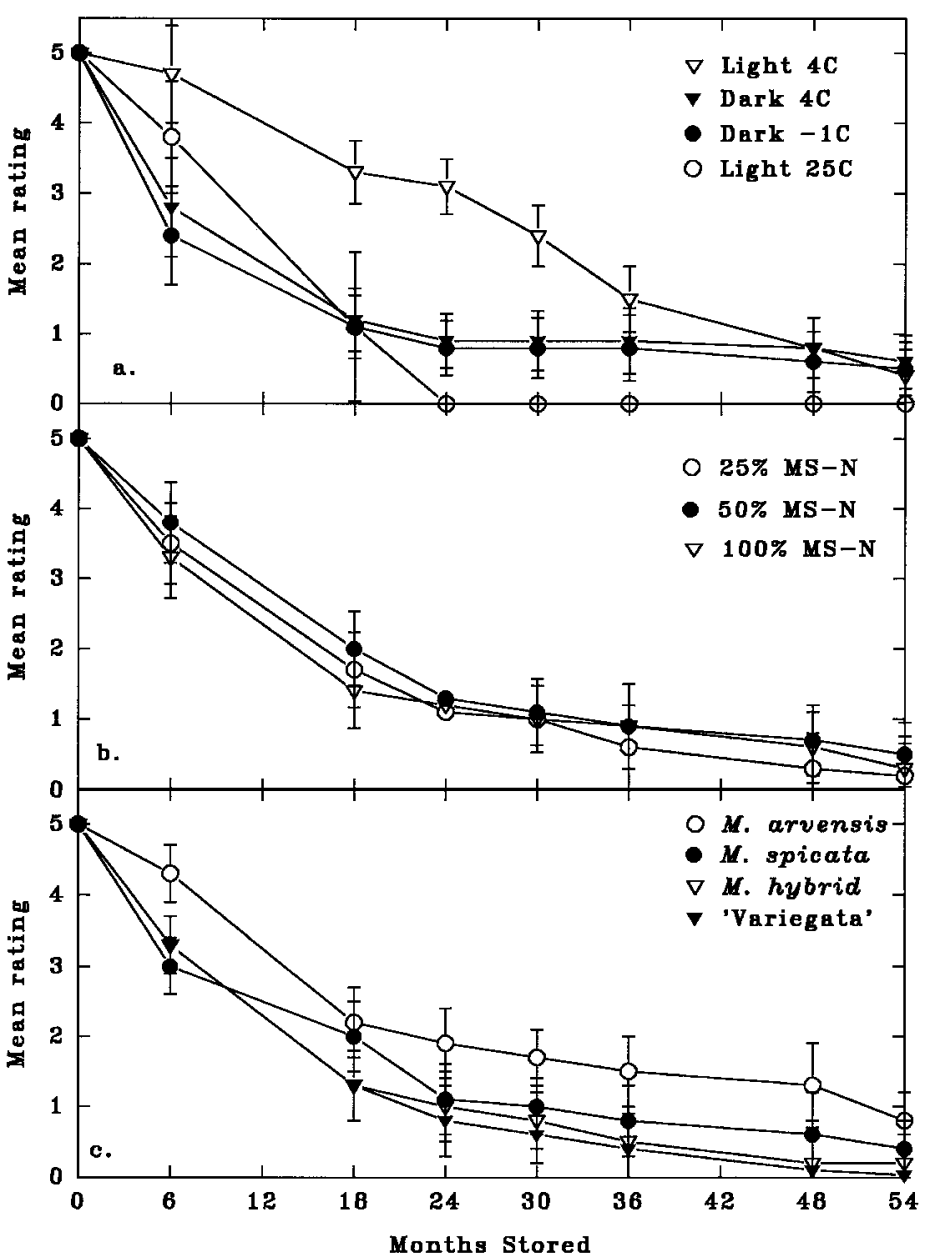

Fig. 1. Mean ratings $( \pm \mathrm{SD})(0=$ dead, $1=$ poor; $5=$ good $)$ for in vitro-grown mint shoots stored in four environments for up to 54 months grouped by: a) storage environment (photoperiod, temperature), b) N concentration in the MS medium (25\%, $50 \%$, or 100\%), and c) genotype (Mentha arvensis, M. spicata, M. suaveolens hybrid, and M. suaveolens cv. Variegata).

Table 2. Analysis of variance of condition ratings $(1=$ poor; $5=$ good $)$ for in vitro-grown shoots of four mint genotypes (Mentha arvensis, $M$. spicata, M. suaveolens hybrid, and $M$. suaveolens $\mathrm{cv}$. Variegata) stored either at $4{ }^{\circ} \mathrm{C}$ in darkness; $4{ }^{\circ} \mathrm{C}$ with a 12 -h photoperiod; or at $-1{ }^{\circ} \mathrm{C}$ in darkness for 24 and 30 months on Murashige and Skoog medium with $25 \%, 50 \%$, or $100 \%$ MS nitrogen concentrations (MS-N).

\begin{tabular}{lccc}
\hline & & \multicolumn{2}{c}{ Mean square } \\
\cline { 3 - 4 } Source & df & 24 months & 30 months \\
\hline Genotype (G) & 3 & $20.1^{* * *}$ & $19.5^{* * * *}$ \\
Environment (E) & 2 & $97.6^{* * *}$ & $47.5^{* * *}$ \\
G $\times$ E & 6 & $5.9^{* * *}$ & $6.1^{* * *}$ \\
MS-N concentration & 2 & 0.7 & $0.2^{* * * *}$ \\
G $\times$ MS-N & 6 & 0.9 & 1.3 \\
E $\times$ MS-N & 4 & 1.4 & $0.6^{* * *}$ \\
G $\times$ E $\times$ MS-N & 12 & $1.6^{* *}$ & $2.2^{* * * *}$ \\
Error & 144 & 0.6 & 0.7 \\
\hline
\end{tabular}

${ }^{*, * * *}$ Significant at $P \leq 0.01$, or 0.001 , respectively.

required. Cold-sensitive genotypes could be stored for 18 months at $25^{\circ} \mathrm{C}$ on $50 \%$ MS-N medium.

\section{Literature Cited}

Ashmore, S.E. 1997. Status report on the development and application of in vitro techniques for the conservation and use of plant genetic resources. Intl. Plant Genet. Resources Inst., Rome.

Buckley, P.M., T.N. DeWilde, and B.M. Reed. 1995. Characterization and identification of bacteria isolated from micropropagated mint plants. In Vitro Cell. Dev. Biol. 31P:58-64.
Chambers, H.L. and K.E. Hummer. 1992. Clonal repository houses valuable mint collection in Corvallis, Oregon. Diversity 8:31-32.

Engelmann, F. 1991. In vitro conservation of horticultural species. Acta Hort. 298:327-332.

Gunning, J. and H.B. Lagerstedt. 1985. Long-term storage techniques for in vitro plant germplasm. Proc. Intl. Plant Prop. Soc. 35:199-205.

Moriguchi, T. and S. Yamaki. 1989. Prolonged storage of grape nodal culture using a low concentration of ammonium nitrate. HortScience 24:372-373.

MSTATC. 1988. MSTATC: A software program for the design, management, and analysis of 


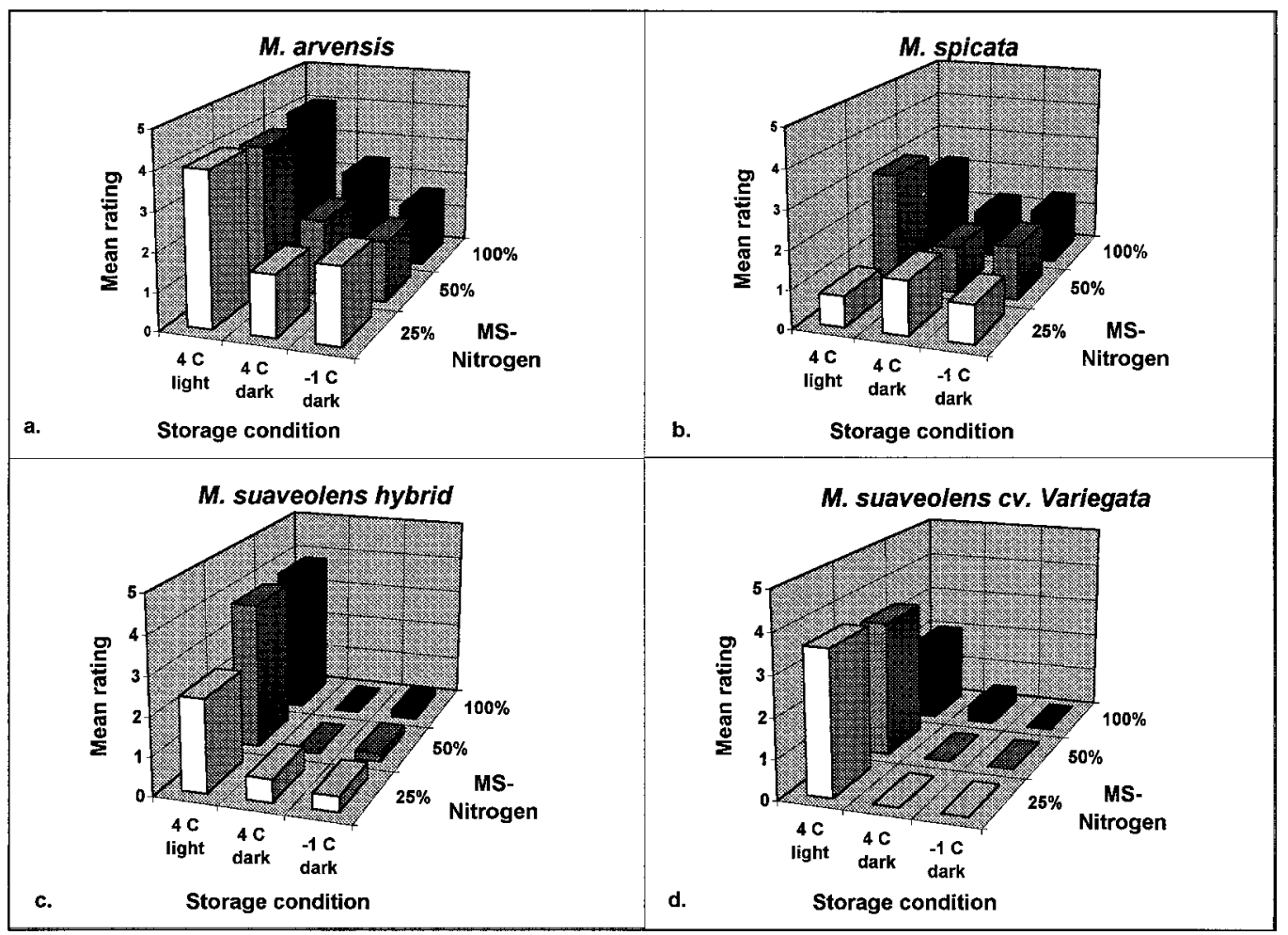

Fig. 2. Nitrogen concentration $\times$ storage condition $\times$ genotype interaction for mint plants stored in vitro for 24 months. (a) M. arvensis; (b) M. spicata; (c) M. suaveolens hybrid; (d) M. suaveolens $\mathrm{cv}$. Variegata.

agronomic research experiments. Michigan State Univ., East Lansing.

Murashige, T. and F. Skoog. 1962. A revised medium for rapid growth and bio-assays with tobacco tissue cultures. Physiol. Plant. 15:473497.

Reed, B.M. 1991. Application of gas-permeable bags for in vitro cold storage of strawberry germplasm. Plant Cell Rpt. 10:431-434.

Reed, B.M. 1993. Improved survival of in vitro- stored Rubus germplasm. J. Amer. Soc. Hort. Sci. 118:890-895.

Reed, B.M., P.M. Buckley, and T.N. DeWilde. 1995. Detection and eradication of endophytic bacteria from micropropagated mint plants. In Vitro Cell. Dev. Biol. 31P:53-57.

Reed, B.M. and Y. Chang. 1997. Medium- and longterm storage of in vitro cultures of temperate fruit and nut crops, p. 67-105. In: M.K. Razdan and E.C. Cocking (eds.). Conservation of plant genetic resources in vitro, vol. 1. Science Publ., Enfield, N.H.

Westwood, M. 1989. Maintenance and storage: Clonal germplasm. Plant Breed. Rev. 7:111128.

Withers, L.A. 1991. In-vitro conservation. Bio. J. Linnean Soc. 43:31-42.

Withers, L.A., S.K. Wheelans, and J.T. Williams. 1990. In vitro conservation of crop germplasm and the IBPGR databases. Euphytica 45:9-22. 